\title{
SLOPE STABILITY ESTIMATION OF THE KOŚCIUSZKO MOUND IN CRACOW
}

\author{
BOGUMIŁ WrANA, NATALIA PIETRZAK \\ Institute of Structures Mechanics, Cracow University of Technology, \\ ul. Warszawska 24, 31-155 Kraków, Poland, \\ e-mail: wrana@limba.wil.pk.edu.pl,nati@silbud.pl
}

\begin{abstract}
In the paper, the slope stability problem of the Kościuszko Mound in Cracow, Poland is considered. The slope stability analysis was performed using Plaxis FEM program. The outer surface of the mound has complex geometry. The slope of the cone is not uniform in all directions, on the surface of the cone are pedestrian paths. Due to its complicated geometry it was impossible to do computing by Plaxis input pre-procesor. The initial element mesh was generated using Autodesk Autocad 3D and next it was updated by Plaxis program. The soil parameters were adopted in accordance with the detailed geological soil testing performed in 2012. Calculating model includes geogrids. The upper part was covered by MacMat geogrid, while the lower part of the Mound was reinforced using Terramesh Matt geogrid. The slope analysis was performed by successives reduction of $\phi / \mathrm{c}$ parameters. The total multiplayer $\Sigma M_{s f}$ is used to define the value of the soil strength parameters. The article presents the results of slope stability before and after the rainfall during 33 days of precipitation in flood of 2010.
\end{abstract}

Key words: soil analysis by FEM, slope stability analysis of soil mound, numerical analysis by PLAXIS program

\section{HISTORY OF THE KOŚCIUSZKO MOUND}

The Kościuszko Mound in Cracow, Poland was erected by Cracovians in commemoration of the Polish national leader Tadeusz Kościuszko. It is an artificial mound modeled after Cracow's prehistoric mounds of Krak and Wanda. A serpentine path leads to the top, approx. 326 meters above the sea level, with a panoramic view of the Vistula River and the city. It was completed in November 1823 . The location selected for the monument was the natural Blessed Bronisława Hill (Polish: Wzgórze bł. Bronisławy), also known as Sikornik, situated in the western part of Cracow's Zwierzyniec District. It is one of Cracow's four mounds.

The construction was financed by donations from Poles living in all territories of Poland under foreign occupation. For three years beginning in 1820, people of all ages and class voluntarily constructed the Mound to the height of 34 meters. Work was supervised by a Committee for the Construction of the Tadeusz Kościuszko Monument. At the base of the Mound, the Founding Act was deposited in a glass and marble case. At the top, a granite boulder, brought from the Tatra Mountains, was placed, bearing the inscription "Kościuszce" (To Kościuszko). Inside the mound, urns were buried with soil from the Polish and American battlefields where Kościuszko fought.

Between 1850-1854, the Austrian authorities built a brick citadel around the Mound and began using it as a strategic lookout. As compensation for an earlier historical church that had been demolished, a neoGothic chapel of Blessed Bronisława was also built. However, the Austrian fortifications, including the gateway and the south-western rampart and entrenchment were eventually dismantled following World War II, between 1945 and 1956.

Next to the Mound there is a museum devoted to Kościuszko, that displays artifacts and mementoes of his life and achievements. In 1997, heavy rains eroded the Mound, thus threatening its existence. It went through a restoration process from 1999 till 2003 in which the state-of-the-art technology and modern materials were used. The top of the Mound was replaced by sandy soil and equipped with a drainage system and a new waterproofing membrane. In 2012, detailed geological soil testing was performed and special electronic sensors were installed to on-line soil monitoring of the mound state. 


\section{REAL GEOMETRY AND SOIL PARAMETERS}

The actual model of the Kościuszko Mound is a very complex entity in terms of geometry and the

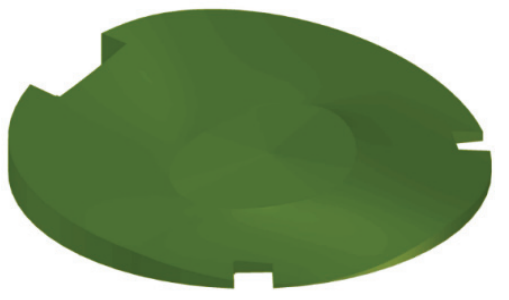

a)

Soil layer III

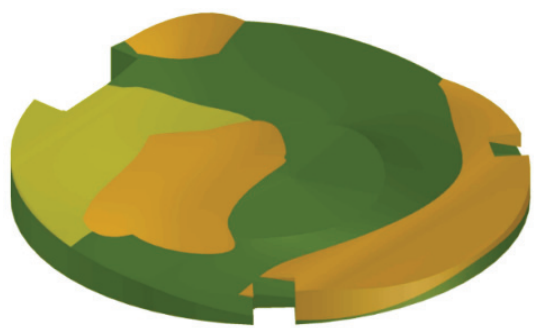

c) Soil layer IIb

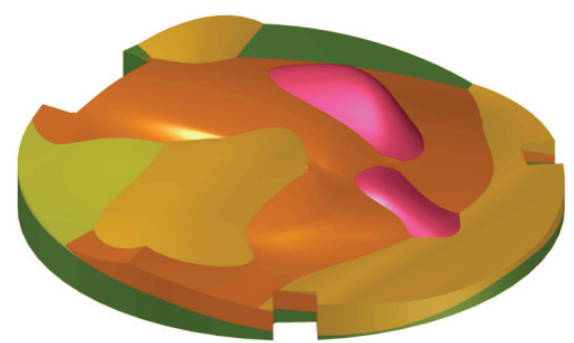

e) Soil layer $\mathrm{Ib}(\mathrm{A})$

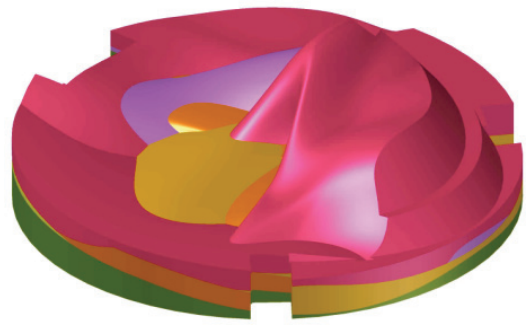

g) Soil layer $\mathrm{Ib}(\mathrm{B})$

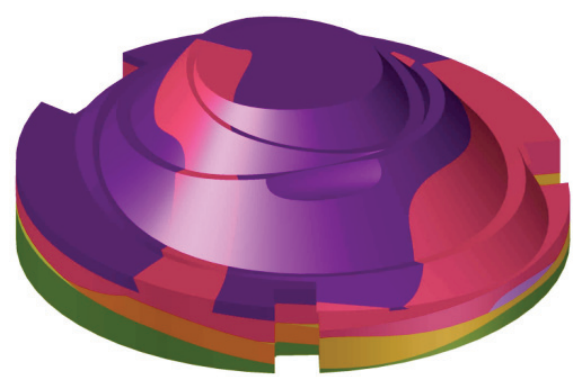

i)

Soil layer $\mathrm{Ib}(\mathrm{C})$ soil layers as well as the groundwater head. This is reflected in Fig. 1a-j. Starting from the bottom of the mound the soil layers are presented, and layers' names describing the figures are in accordance with the Geology Engineering Report [6].

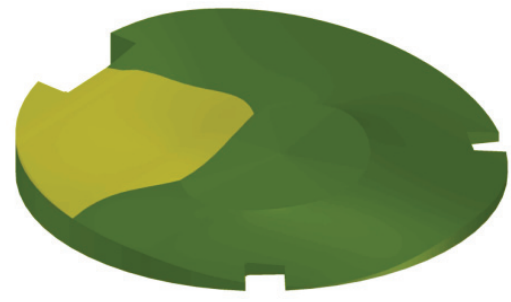

b) Soil layer IIc

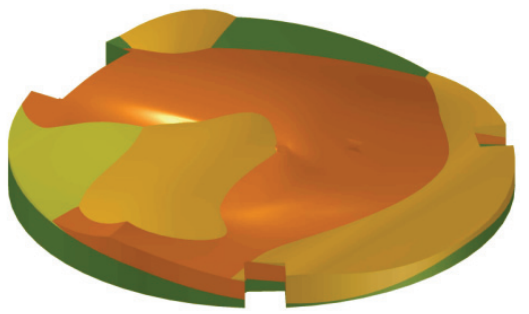

d)

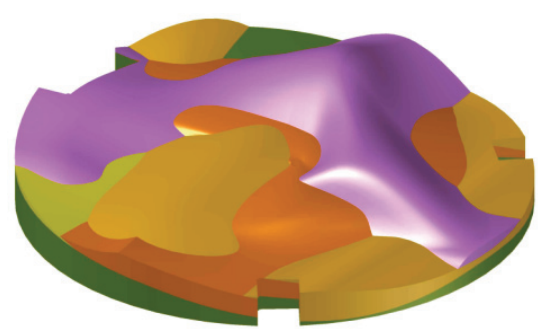

f)

Soil layer Ic

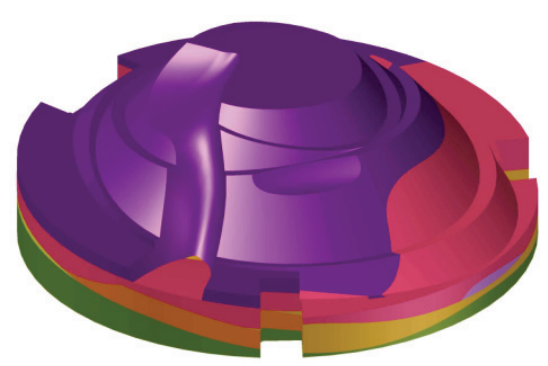

h) Soil layer Ia

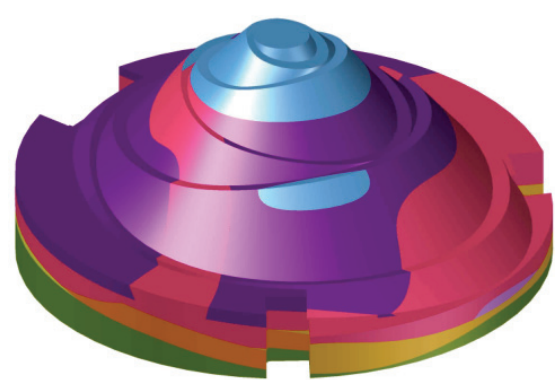

Soil layer Id

Fig. 1. Soil layers of the Kościuszko Mound 
Table 1. Soil parameters of the Kościuszko Mound layers

\begin{tabular}{|c|c|c|c|c|c|c|c|c|}
\hline No. & Soil & $\begin{array}{c}\text { Moisture } \\
w_{n}[\%]\end{array}$ & $\begin{array}{l}\text { Volume } \\
\text { density } \\
{\left[\mathrm{g} / \mathrm{cm}^{3}\right]}\end{array}$ & $\begin{array}{l}\text { Index } \\
I_{\mathrm{L}} / I_{\mathrm{D}}\end{array}$ & $\begin{array}{c}\text { Friction } \\
\text { angle } \\
\left.{ }^{\circ}\right]\end{array}$ & $\begin{array}{c}\text { Cohesion } \\
{[\mathrm{kPa}]}\end{array}$ & $\begin{array}{c}\text { Odometer } \\
\text { modulus } \\
\text { Mo }[\mathrm{MPa}]\end{array}$ & $\begin{array}{c}\text { Odometer } \\
\text { modulus } \\
M[\mathrm{MPa}]\end{array}$ \\
\hline $\mathrm{Ia}, \mathrm{Ia}_{\mathrm{k}}$ & $\begin{array}{l}\mathrm{Si}, \mathrm{clSi} \text {, saclSi, } \\
\text { siCl, sasiCl }\end{array}$ & 14.0 & 2.149 & -0.20 & 24 & 33 & 12.4 & 33.0 \\
\hline $\mathrm{Ib}, \mathrm{Ib}_{\mathrm{k}}$ & clSi, sac & 18.9 & 2.094 & 0.11 & 20 & 29 & 8.0 & 21.0 \\
\hline Ic, $\mathrm{Ic}_{\mathrm{k}}$ & $\begin{array}{l}\text { clSi, saclSi, } \\
\text { siCl,sasiCl }\end{array}$ & 24.5 & 2.013 & 0.35 & 14 & 20 & 6.4 & 17.0 \\
\hline $\mathrm{Id}, \mathrm{Id}_{\mathrm{k}}$ & $\begin{array}{l}\text { MSa, grSa, } \\
\text { grsiSa, saGr, } \\
\text { sisaGr }\end{array}$ & 6.0 & 1.967 & 0.36 & 30 & & 30.0 & \\
\hline IIa & clSi, saclSi & 13.9 & 2.123 & -0.23 & 25 & 32 & 13.4 & 35.5 \\
\hline IIb & $\begin{array}{l}\text { clSi, saclSi, } \\
\text { sasiCl }\end{array}$ & 19.1 & 2.088 & 0.10 & 18 & 30 & 8.0 & 21.4 \\
\hline III & $\begin{array}{l}\text { clSi, saclSi, } \\
\text { siCl, sasiCl }\end{array}$ & 25.4 & 2.049 & 0.35 & 11 & 28 & 7.7 & 18.0 \\
\hline $\operatorname{IId}_{\mathrm{k}}$ & $\begin{array}{l}\text { clSi, saclSi, } \\
\text { siCl, sasiCl }\end{array}$ & 28.2 & 1.884 & 0.54 & 9 & 15 & 5.2 & 15.0 \\
\hline III & limestone & & 2.30 & & & & & \\
\hline
\end{tabular}

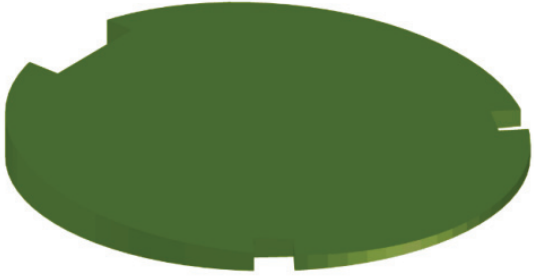

a) Soil layer III

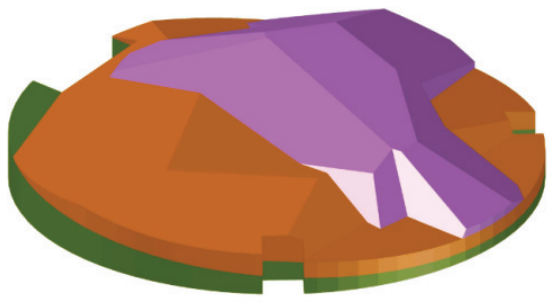

c) Soil layer Ic

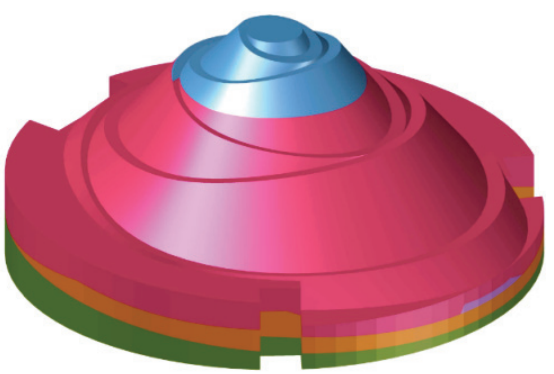

e)

Soil layer Id

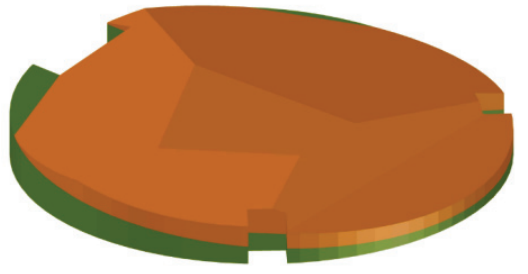

b) Soil layers IIa, IIb, IIc

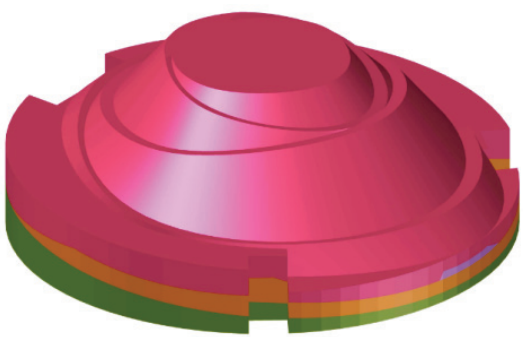

d) Soil layers Ia, Ib

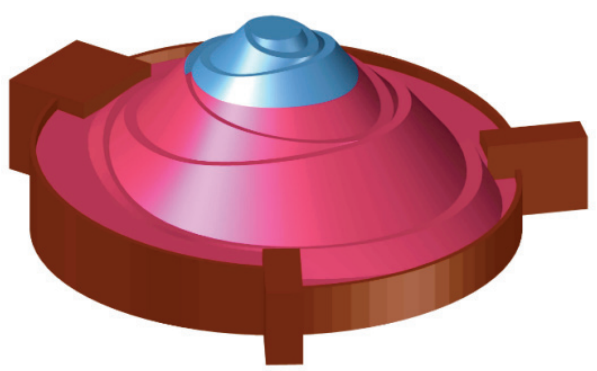

f) Mound with brickwall

Fig. 2. Calculation of simplified soil layers 
Soil parameters have been calculated on the basis of geological studies carried out in 2012 (annex A13 of Geology Engineering Report [6]). Table 1 summarizes the characteristics for the subsequent layers. Some of the relevant parameters which were not described in the Geology Engineering report had to be calculated or read from literature [1], [N1], [N2]. Those are Young's modulus, Poisson ratio, void ratio. Parameters of separate layers are shown in Table 1.

The main mound is made of cohesive soils and below there are layers of limestone. The MohrCoulomb and Cam-Clay macromechanical models of plasticity theory were used to mound soil layers. The two main model parameters appearing in the yield criterion and strain hardening/softening rule are the friction angle $\phi$ and cohesion $c$ [1]-[3]. The Hoek -Brown rock model [5] as non-linear approximation of the strength of rocks was introduced to the limestone base layers of the mound. The material behavior of rock may be different from the behavior and numerical model, generally it may be stiffer and stronger. Furthermore, rock may also show a significant tensile strength.

\section{SIMPLIFICATION OF MATERIAL MODEL}

Layers of soil described in the previous section (Fig. 1) have a complex geometry. Such a number of layers of complex shape leads to element mesh excess computing capabilities. Two steps were taken in order to simplify the real model of the Mound. The first - soil layers with similar geotechnical parameters have been merged and their contact layers tailored according to the Plaxis' capabilities of computing, as shown in Fig. 2. In the next one - volume average parameters were used in numerical calculations.

\section{FEM MESH OF THE KOŚCIUSZKO MOUND}

The outer surface of the mound has a complex geometry. The slope of the cone is not uniform in all directions, on the surface of the cone there are pedestrian paths. Due to its complicated geometry it was impossible to perform it by Plaxis input preprocesor. Autodesk Autocad 3D with triangulation mesh is used to obtain initial FEM mesh, as shown in Fig. 3.

In places of pedestrian path crossings AutoCAD, as a standard, generates small tetrahedron mesh elements. In the next steps of data preparation, correction of the geometry of pedestrian paths was introduced, so that the mesh was composed of elements of similar size. The area near pedestrian paths required finer mesh while the base area of the mound (limestone) did not require this. The calculation model has about 60 thousand nodes. The mesh generation process by itself also takes into account the soil stratigraphy as well as all structural objects, load or boundary conditions. The basic elements of the 3D finite element mesh of Plaxis program used 10-node tetrahedral elements [4] as in Fig. 4. The finite element mesh is presented in Fig. 4.

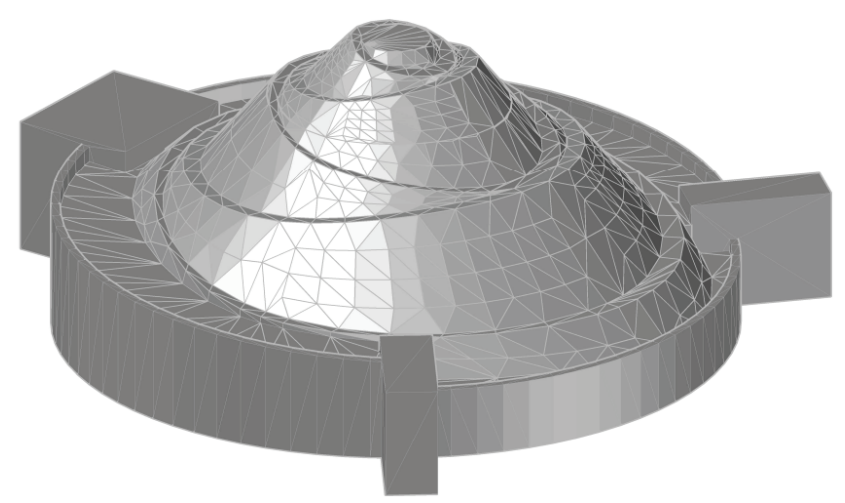

Fig. 3. Mound simplified model after triangulation

As was explained before, some of the layers of the soil due to their similarity were merged and their physical parameters averaged. The inner part of the mound drainage was also modelled, as shown in Fig. 5.

The outer surface of the mound was stabilized with geogrids and was covered by MacMat geogrid, while the lower part of the Mound was reinforced using Terramesh Matt geogrid. It is presented in Fig. 6, where depending on the strength of geogrids, the mound is covered with varying shades of yellow. Geogrids are composed of 6-node triangular surface elements with three translational degrees of freedom per node. The material parameters for a geogrid are the axial stiffness EA [4].

In the next step of calculation, the rainfall during the flood of 2010 was modelled. A total of 33 days of precipitation are presented in the chart (Fig. 7) and applied as the "main load" - precipitation in Plaxis application. 

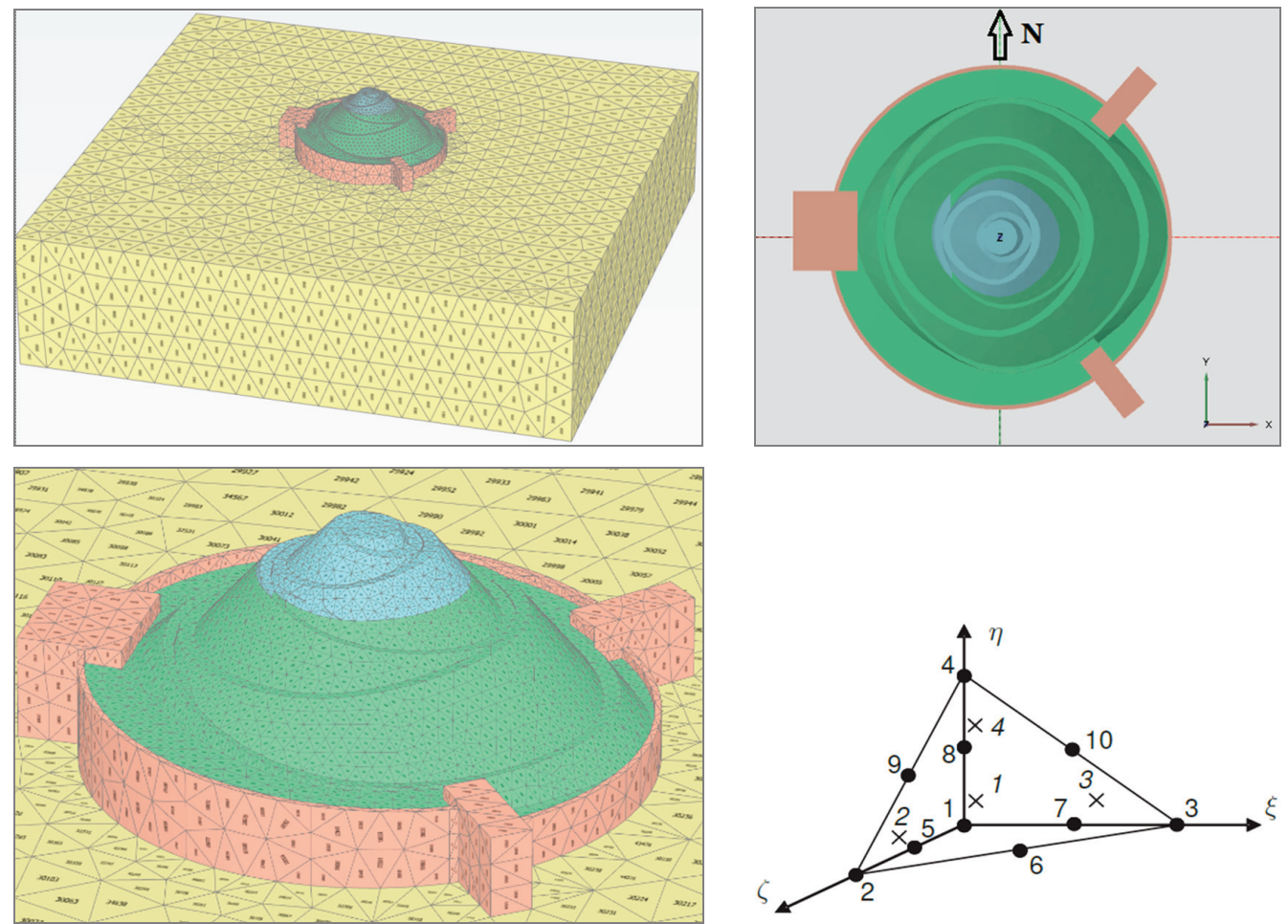

Fig. 4. Finite element mesh in Plaxis application, general view with the enlargement of the Mound area and showing the north face

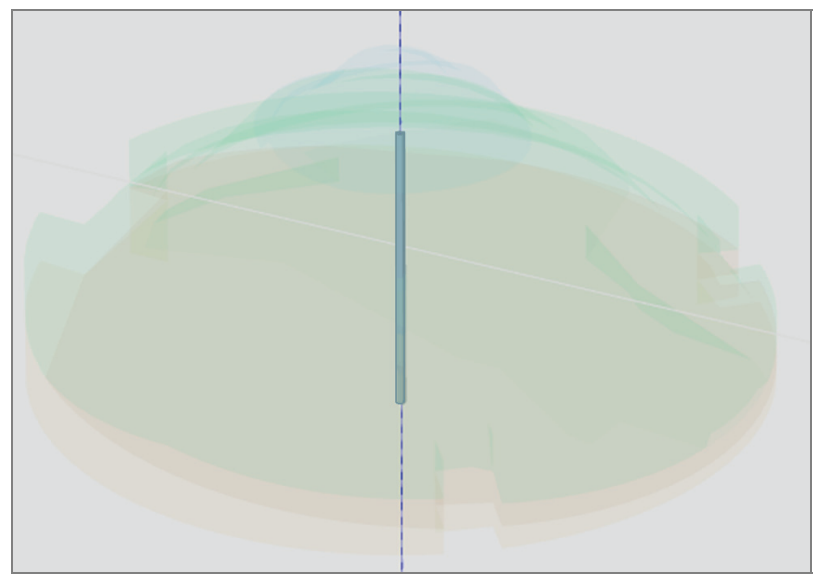

Fig. 5. Central drainage of the upper part of the mound

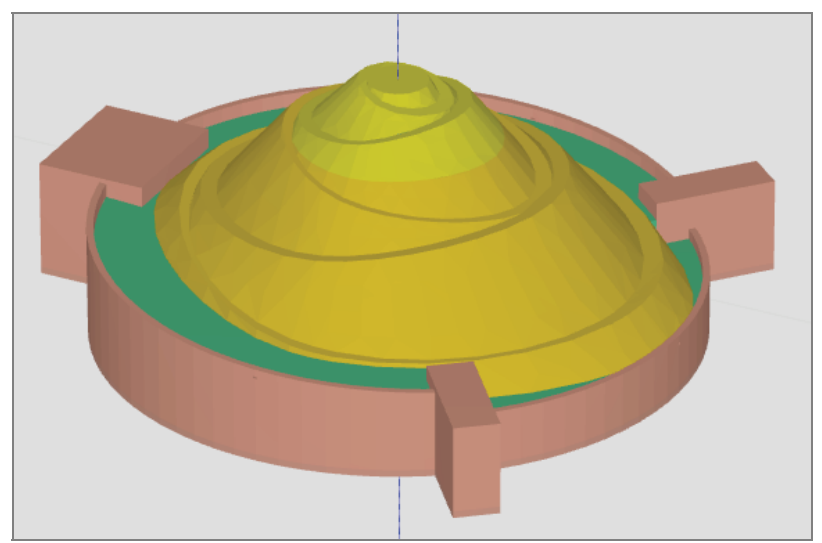

Fig. 6. Terramesh and Mac Mat geonet modelled in Plaxis application

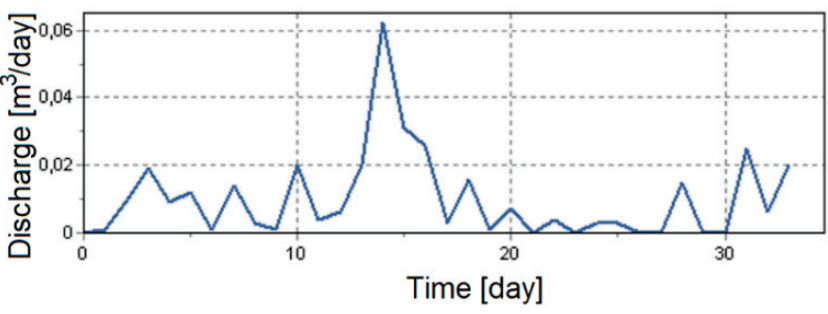

Fig. 7. The chart of 33 days of intense rainfall in 2010

\section{SLOPE STABILITY ESTIMATION}

\subsection{INITIAL STRESS EQUILIBRIUM CALCULATION}

Before the start of the slope stability estimation a stress balance inside mound volume should be obtained. This is achieved by introducing a mound model in several steps (see Fig. 8). At first, mound layers from the lowest to the highest are introduced, together with their parameters. Plaxis program starts the stability calculation in the stress state equilibrium after completing the stages of the mound construction (after consolidation). 

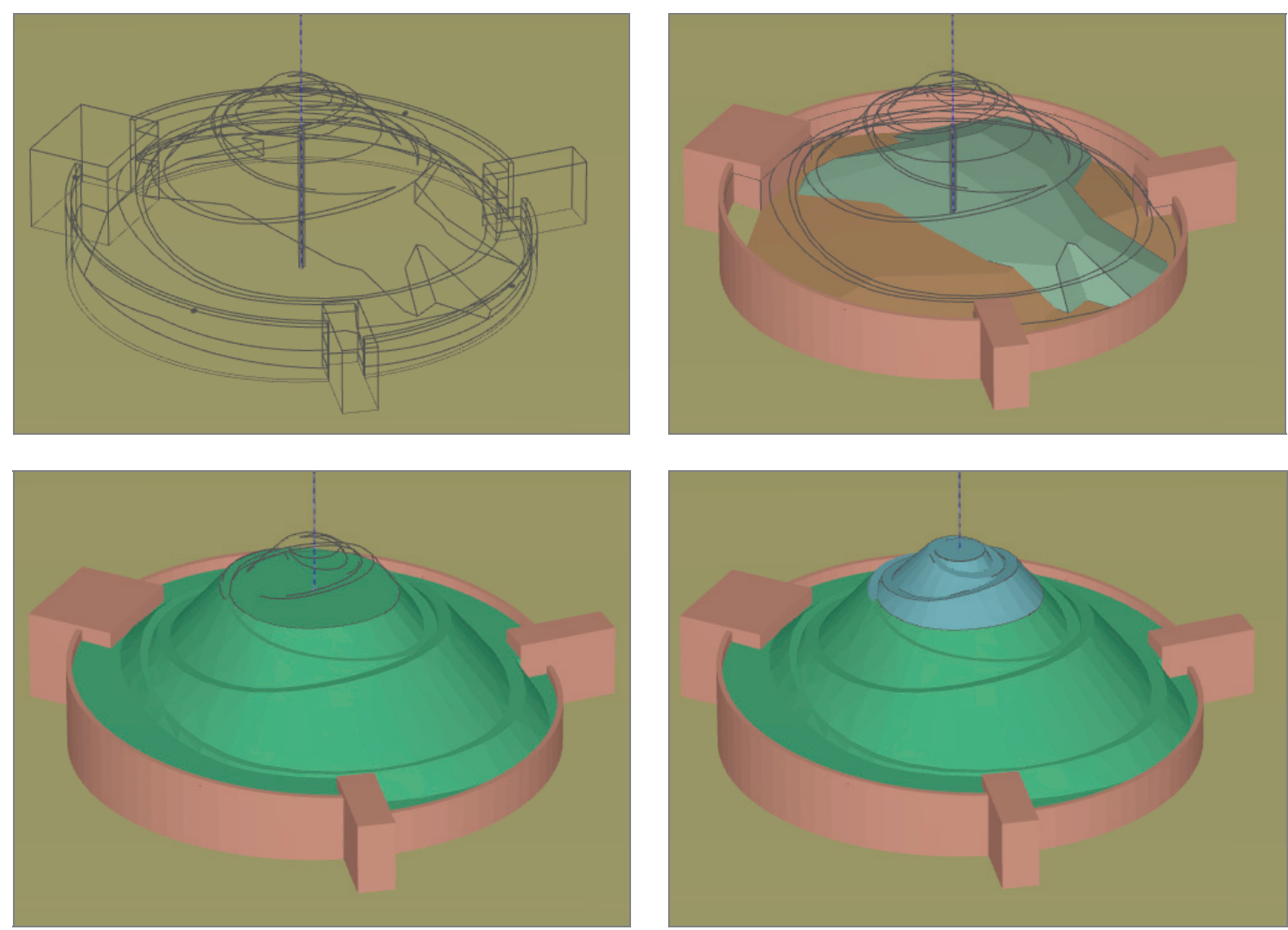

Fig. 8. Construction steps of the Mound to obtain the stress equilibrium

\subsection{CALCULATION METHOD}

In the slope analysis [4] the strength parameters $\tan \phi$ and $c$ of the soil are successively reduced until slip failure of the structure occurs. The dilatancy angle $\theta$ is, in principle, not affected by the $\phi / c$ reduction procedure. However, the dilatancy angle can never be larger than the friction angle. The strength of structural objects like geotextile reinforcement and anchors, if used, are not influenced by a safety $\phi / c$ reduction.

The total multiplayer $\Sigma M_{s f}$ definition is used to define the value of the soil strength approximation at a given stage in the analysis

$$
\sum M_{s f}=\frac{\tan \phi_{\text {input }}}{\tan \phi_{\text {reduced }}}=\frac{c_{\text {input }}}{c_{\text {reduced }}}
$$

where the strength parameters with the subscript "input" refer to the properties entered in the material sets, and parameters with the subscript "reduced" refer to the reduced values used in the analysis. At the start of calculation $\Sigma M_{s f}$ is set to 1.0, which means that all material parameters are equal to their input values.

As was explained above the strength parameters are successively reduced automatically in the application until the given number of steps has been performed. The factor of safety is given by
$S F=\frac{\text { available strength }}{\text { strength atfailure }}=$ value of $\sum M_{s f}$ at failure.

Plaxis program not only allows us to view the scope of failure area but also helps us to determine the value of safety factor $\Sigma M_{s f}$.

\subsection{SLOPE STABILITY ESTIMATED CASES}

Slope stability analysis has been investigated in two cases - for the non-irrigated and irrigated mound (after 33 days of intense rainfall). Figure 9 presents calculation result of stability problem before irrigation and Fig. 10 presents calculation after irrigation.

The calculation results show that the differences in the results of stability before and after irrigation are very small (see Fig. 11) and are greater in the case of irrigated mound. The tendency of a structure to tilt to the East in both cases can be observed.

Moreover, the results indicate that the irrigation does not change layer parameters $\phi / \mathrm{c}$, which means that water does not percolate but flows on the external surface of the mound. 

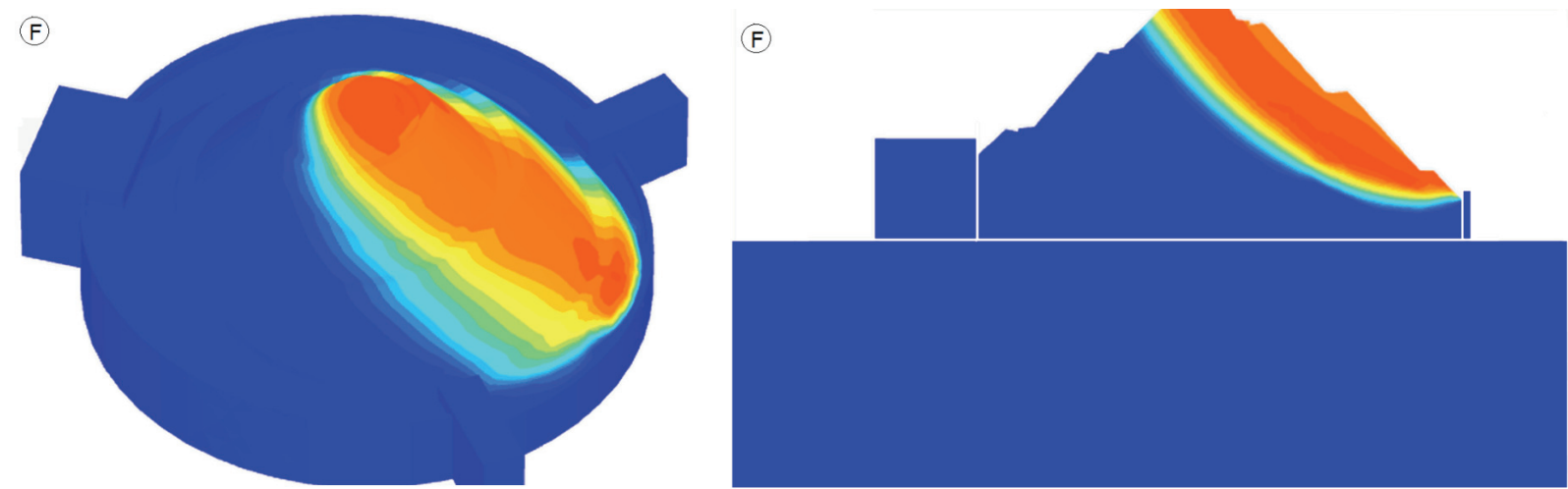

Fig. 9. Scope of slip area in the case of non-irrigated mound
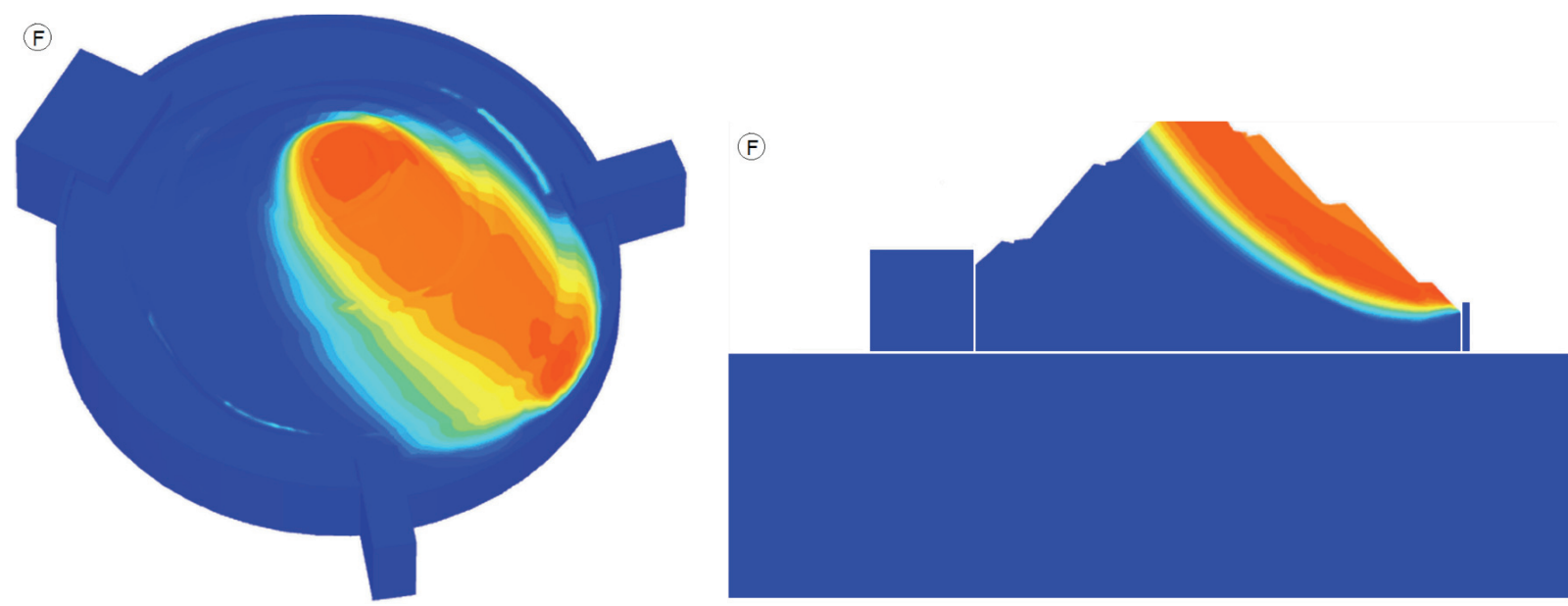

Fig. 10. Scope of slip area in the case of irrigated mound after 33 days of heavy rainfall (similar shape to Fig. 9, see Fig. 11)

\subsection{DEFORMATION STEPS}

In order to identify steps of stability deformation shown in Fig. 11, the additional static calculations were carried out. The cohesion $c$ and tangent of the friction angle $\phi$ were gradually reduced. In Fig. 12, we can see the total mound displacements for $2 \%, 3 \%, 5 \%$ and $7 \%$ reduction steps of the $\phi / c$ parameters. Slope stability results in Fig. 9 and Fig. 10 correspond to the maximum deformation " $F$ " presented in Fig. 11.

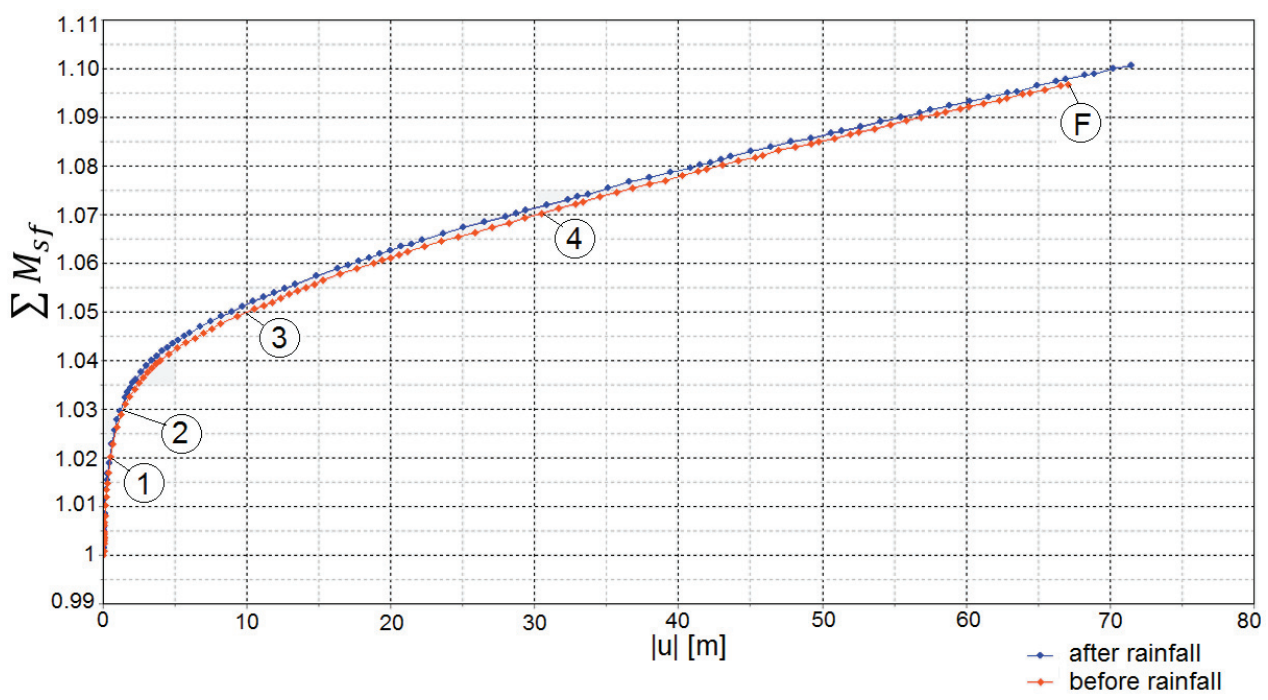

Fig. 11. Safety factor result for both cases - before and after heavy rainfall 

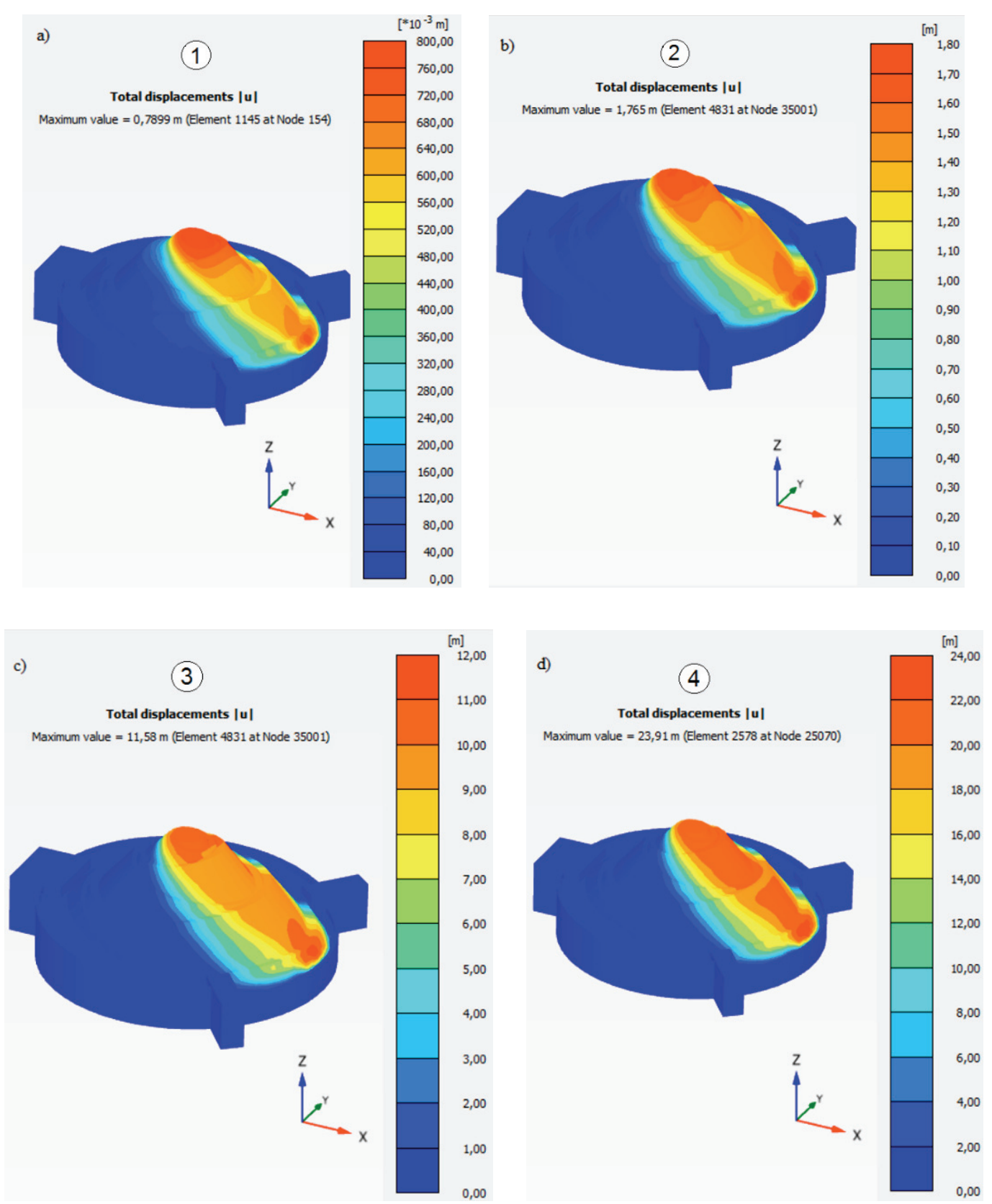

Fig. 12. Total displacements for (a) $2 \%$, (b) $3 \%$, (c) $5 \%$, (d) $7 \%$ reduction of cohesion and tangent of friction angle
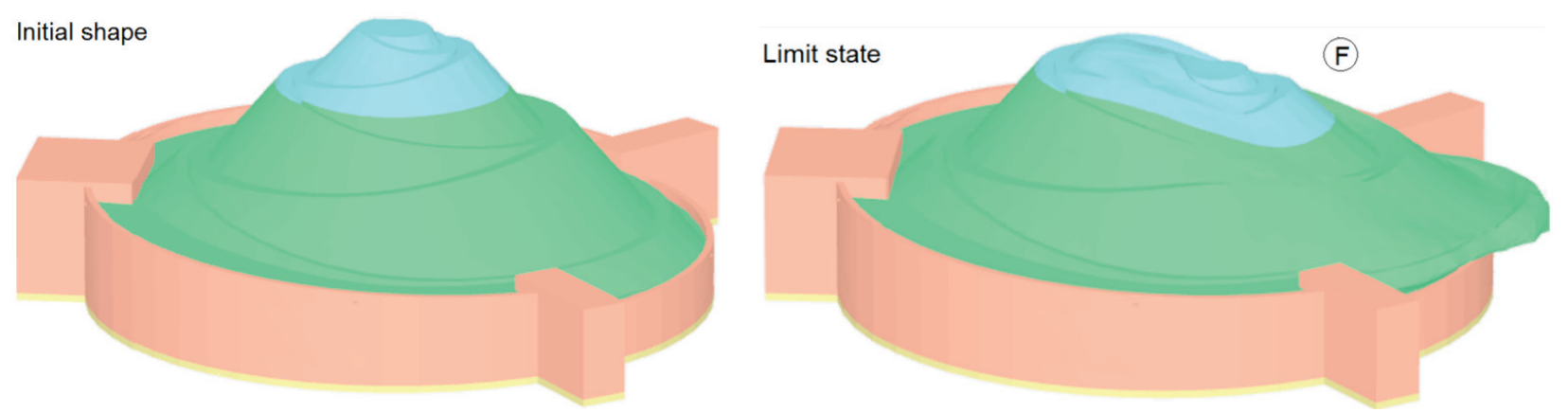

Fig. 13. Deformed mesh for the $10 \%$ reduction of cohesion and tangent of friction angle 
Figure 13 presents deformation of the Kościuszko Mound after reduction of $10 \%$ parameters $\phi / \mathrm{c}$.

\section{CONCLUSION}

The Kościuszko Mound in Cracow was erected by Cracovians from the local ground cohesion soils, mainly silty-clays found close to the city. It is a historic specified ground structure protected by the law. The authors' intention was to estimate the stress and strain state by using the actual computational methods and estimating characteristic value of slope stability factor. Actually, in computer programs, estimation of slope mound stability is based on the total multiplayer $\Sigma M_{s f}(1)$, which gradually reduces the cohesion $c^{\prime}$ and tangent of the friction angle $\phi^{\prime}$. Figure 11 shows changes of deformation with decrease of soil parameters, and one can observe that:

- for both cases, before and after heavy rainfall the results are similar,

- the shape of curvatures indicated that the total multiplayer $\Sigma M_{s f}$ is proportional to reduce the cohesion $c^{\prime}$ and tangent of the friction angle $\phi^{\prime}$,

- it can be observed that very small parts of curves describe elastic range (app. 1\%), the others described constant unlimited hardening of soil layers,

- constant growing deformation after having reached the limit value of $\Sigma M_{s f}$ is not observed, which means that for this ground structure, it is not pos- sible to obtain characteristic value of the safety factor defined by $S F(2)$.

\section{REFERENCES}

[1] Wrana B., Soil dynamics. Calculation models, Published by Cracow University of Technology, Kraków, 2012 (in Polish).

[2] Wrana B., Lectures on soil mechanics, Published by Cracow University of Technology, Kraków, 2014.

[3] Wrana B., Laboratory Testing of Soil Mechanics, Published by Cracow University of Technology, Kraków, 2015.

[4] Reference Manual, PLAXIS 3D 2013.

[5] Material Models, PLAXIS 3D 2013.

[6] Dokumentacja geologiczno-inżynierska dla rozpoznania podłoża, dla potrzeb opracowania zabezpieczenia obiektu stożka Kopca Kościuszki wraz z otoczeniem, Przedsiębiorstwo geologiczne S.A., Kraków, styczeń 2013.

\section{STANDARDS}

[N1] PN-EN 1997-1: Eurocode 7: Geotechnical design - Part 1: General rules.

[N2] PN-EN 1997-2: Eurocode 7: Geotechnical design - Part 2: Ground investigation and testing.

[N3] PN-81/B-03020: Building soils. Shallow foundation of buildings. Statics calculation and designing (in Polish).

[N4] PN-EN ISO 14688-1: Geotechnical investigation and testing. Identification and classification of soil. Part 1. Identification and description.

[N5] PN-EN ISO 14688-2: Geotechnical investigation and testing. Identification and classification of soil. Part 2. Principles for a classification.

[N6]PN-88/B-04481: Building soils. Laboratory tests (in Polish). 